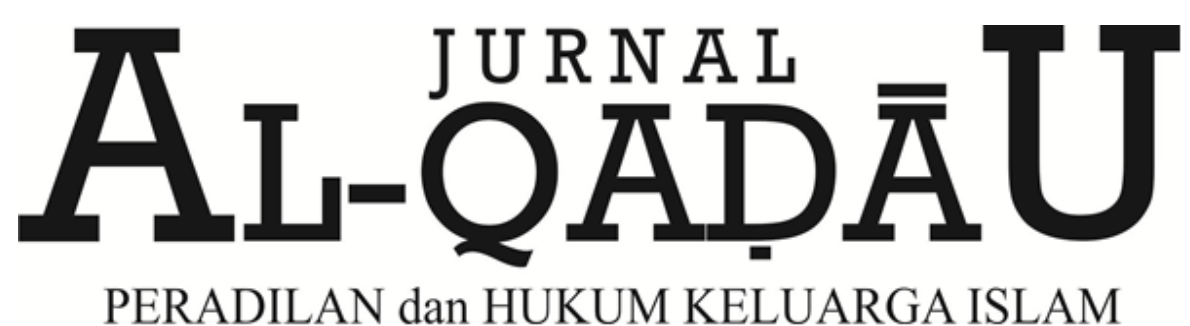

\title{
Positivisasi Syariat Islam di Indonesia
}

The Positivization of Islamic Law in Indonesia

Andi Safriani

Dosen UIN Alauddin Makassar

Email : aydinriany13@gmail.com

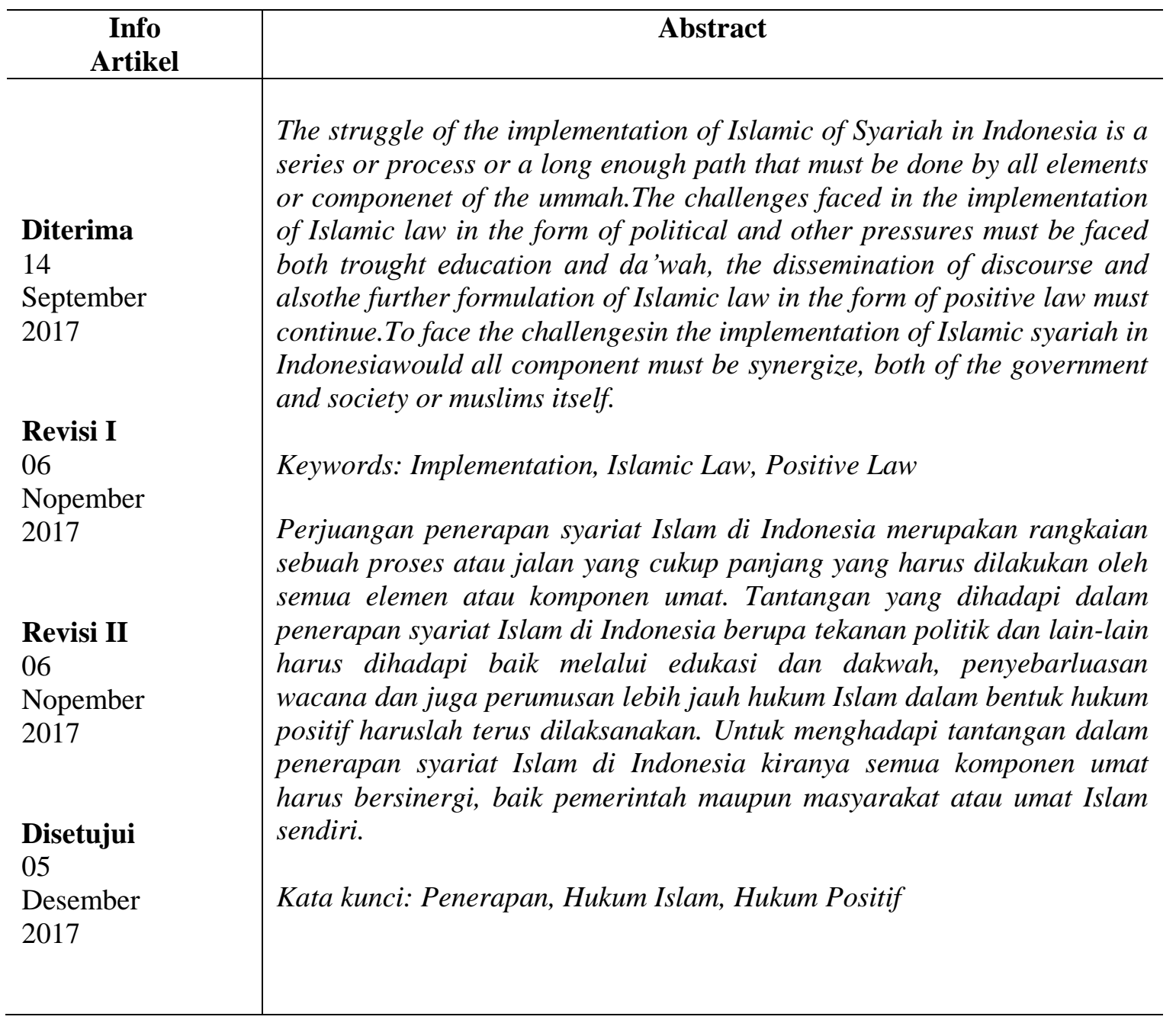




\section{PENDAHULUAN}

\section{A. Latar Belakang Masalah}

Ajaran Islam dikenal sebagai ajaran penutup pada semua kenabian dan kerasulan, selain menuntut adanya pemahaman yang benar atas statusnya sebagai ajaran pamungkas atau penutup, yang tentunya mengakomodosi dan menuntaskan permasalahan ajaran-ajaran samawi sebelumnya.

Islam dalam pandangan banyak pemikir, memiliki sistematika ajaran yang sangat kompleks dan menyapa berbagai problema kemanusiaan. Hal ini dimungxkinkan sebab Islam mempunyai akar sejarah yang panjang tentang proses pemanusiaan manusia. Kehadiran Nabi Muhammad SAW bisa dimaknai dalam kerangka pembebasan demi kesejahteraan dan kedamaian manusia sebagai penghuni bumi melalui ajaran yang bersumber dari Al Quran dan Sunnahnya.

Dewasa ini banyak sekali permasalahan-permasalahan fundamental yang terjadi dalam praktek kehidupan seorang muslim. Dasar ajaran Islam yang terdiri dari aqidah, syariah dan akhlak sering kali dilupakan keterkaitannya.

Bagi kaum muslim, penerapan syariat Islam menjadi bagian dari kehidupan sehari-hari, baik secara pribadi, keluarga, masyarakat maupun negara. Ibadah sholat, zakat, haji, pernikahan, perdagangan dan sebagainya adalah sebagian aspek kehidupan yang terikat erat dengan syariat.

Pengkajian tentang wacana syariat Islam memang menarik dan tidak akan terhenti karena hal ini menjadi sebuah dinamika keagamaan yang berkembang dalam masyarakat. Syariat Islam diturunkan kepada umat manusia agar menjadi petunjuk dan rahmat terhadap semesta alam (Rahmatan lil Alamin), sehingga dengan menjalankan syariat Islam yang telah ditunjukkan Allah dan Rasulnya maka niscaya manusia akan hidup tentram disunia dan diakhirat.

Di Indonesia, merunut sejarah perjalanan perjuangan penerapan syariat Islam di negara kita ini ternyata sudah sering dilakukan, baik itu melalui jalur parlemen atau pemerintahan atau menggunakan jalur konfrontatif diluar pemerintahan.

Saat ini, banyak tafsir akan makna serta tujuan syariat Islam yang berkembang dalam masyarakat, menjadikan penerapan serta penegakannya pun berbeda-beda. Maraknya peraturan daerah berbasis syariat Islam tidak bisa dilepaskan dalam konteks dinamika keagamaan saat ini, hal ini disebabkan karena terbukanya peluang lewat 
otonomi daerah, serta aspirasi permanen kelompok islam untuk memasukkan hukum Islam dalam hukum Nasional setelah gagal mengamandemen UUD, akhirnya kecenderungan itu bergeser dari tingkat pusat ketingkat daerah melalui Peraturan Daerah. Padahal Peraturan Daerah (Perda) yang bernuansa Islami tersebut bisa saja mennyimpan potensi masalah dan bisa menimbulkan kecemburuan antara warga.

Indonesia dengan mayoritas penduduknya yang beragama Islam merupakan sebuah komunitas muslim terbesar di dunia. Ironisnya, dengan jumlah yang besar tersebut tidaklah cukup menggambarkan bagaimana umat Islam di Indonesia menjadi umat yang terhormat dibawah naungan syariat Islam yang mulia tersebut. Di Indonesia kita bisa melihat kemiskinan, kebodohan, korupsi, kriminalitas dan beragam permasalahan bangsa yang terjadi, sebuah kondisi yang sangat kontradiktif dengan apa yang menjadi ajaran bagi umat Islam. Idealnya jika ajaran Islam benar-benar diterapkan dan dilaksanakan dalam kehidupan manusia, termasuk dalam kehidupan berbangsa dan bernegara tentulah Indonesia akan menjadi negeri yang baldatun warobbun ghofur.

\section{B. Rumusan Masalah}

Berdasarkan uraian singkat dalam latar belakang masalah yang dikemukan tersebut diatas, maka penulis tertarik untuk mengkaji atau membahas lebih jauh dalam dalam penulisan makalah ini dengan merumuskan masalah yakni: "Bagaimanakah tantangan dalam penerapan syariat Islam di Indonesia?”.

\section{PEMBAHASAN}

\section{A. Pengertian Syariat}

Syariah berasal dari bahasa Arab yang arti etimologisnya adalah jalan yang harus dituruti (Fyzee, dalam Arfin Hamid 2011:35), atau jalan yang lurus (Zuhdi dan Ziraj dalam Arfin Hamid 2011:36). Sedangkan berdasarkan Istilah atau terminologisnya, syariah diartikan oleh beberapa pakar hukum Islam sebagai berikut: ${ }^{1}$

1. Fyzee (1965: 23), mengemukakan syariat dalam bahasa Inggris sebagai Common of law, yakni keseluruhan perintah Tuhan. Tiap-tiap perintah itu dinamakan hukum.

\footnotetext{
${ }^{1}$ Arfin Hamid, Hukum Islam Perspektif ke Indonesiaan (Sebuah Pengantar dalam Memahami Realitasnya), (PT. Umitoha Grafika: Makassar, 2011), h. 36.
} 
Hukum Allah tidak mudah dipahami dan syariah itu meliputi semua tingkah laku manusia.

2. Agnides (1984: 13) mengemukakan syariah adalah sesuatu yang tidak akan diketahui adanya, seandainya tidak ada wahyu ilahi.

3. Hanafi (1984:9) memberikan pengertian syariah adalah apa hukum-hukum yang diadakan oleh Tuhan untuk hamba-hambanya yang dibawa oleh salah seorang nabi Nya, baik hukum-hukum tersebut berhubungan dengan cara mengadakan perbuatan maupun mengenai hal yang berhubungan dengan kepercayaan.

4. Rosyada (1995:1) mengemukakan syariah adalah menetapkan norma-norma hukum untuk menata kehidupan manusia baik dalam hubungannya dengan Tuhan maupun dengan umat manusia lainnya.

5. Zuhdi (1987:1) memberikan pengertian tentang syariah sebagai hukum yang ditetapkan Allah SWT melalui Rasul Nya untuk hamba Nya agar mereka menaati hukum itu atas dasar iman, baik yang berkaitan dengan akidah,amaliyah (ibadah muamalah) dan yang berkaitan dengan akhlak.

Dari pengertian tersebut nampak jelas bahwa syariah Islam adalah syariah yang paling luas karena tidak hanya terbatas pada masalah kejiwaan saja, melainkan termasuk pula hukum-hukum akidah atau kepercayaan, hukum-hukum akhlak atau budi pekerti, dan hukum-hukum tentang amaliyah (ibadah dan muamalah).

Muhammad Yusron Hadi mendefenisikan syariat sebagai hukum yang telah ditetapkan oleh Allah SWT bagi hamba-hamba Nya, agar mereka menjadi orang yang beriman dan beramal sholeh dalam kehidupannya, baik yang berkaitan dengan perbuatan, akidah maupun akhlak. Sedangkan menurut Mahmud Syaitut, Syariat adalah peraturan yang ditetapkan oleh Allah bagi hamba Nya untuk di ikuti dalam hubungannya dengan Allah, dengan saudaranya sesame muslim, dengan saudaranya sesame manusia, dan berhubungan dengan alam semesta serta berhubungan dengan kehidupan.

Dari defenisi tersebut dapat diketahui bahwa makna syariat sesungguhnya mengandung dua arti, Pertama, Seluruh ajaran agama yang mencakup aqidah, ibadah, akhlak dan muamalah. Kedua, sisi hukum amaliah didalam agama, seperti ibadah dan 
muamalah yang mencakup hubungan dengan Allah dan mencakup juga urusan keluarga, masyarakat, umat, bahkan negara.

\section{B. Kewajiban Menegakkan Syariat}

Kewajiban menegakkan syariat Islam merupakan perintah Allah SWT, agar kita berpegang teguh dalam menegakkan syariat Islam hukum yang mengatur kehidupan kita di dunia agar tujuan dari syariat dapat dirasakan bersama manfaatnya. Allah SWT mewajibkan hal ini kepada hamba Nya serta menjadikannya sebagai tujuan diturunkannya Al Quran, sebagaimana Firman Nya dalam Surah Al Baqarah ayat 213, yang terjemahannya sebagai berikut:

"Dan Allah menurunkan kitab suci bersama Rasul dengan haq agar mereka memutuskan perkara yang diperselisihkan diantara mereka”.

Allah SWT lebih lanjut menerangkan bahwa hak khusus Allah semata untuk membuat Hukum sebagaimana dalam Firman Nya (QS.Al An'am:57):

"Sesungguhnya hak menetapkan hukum itu hanya hak Allah. Allah menetapkan kebenaran dan Dialah sebaik-baik pemberi keputusan.

Ayat tersebut diatas dapat memberikan gambaran bahwa berhukum dengan hukum Allah merupakan realisasi pengakuan rela Rasulullah SAW sebagai nabi dan rasulnya. Imam ibnu qayyim Al Jauziyah berkata adapun ridho dengan nabi nya sebagai rasul mencakup sikap tunduk sepenuhnya kepada Nabi Muhammad SAW dan menyerahkan diri secara mutlak kepada Rasulullah sehingga ia tidak menerima petunjuk kecuali yang bersumber dari ajaran Rasulullah SAW.

Berhukum dengan hukum Allah merupakan makna syahadat "Aku bersaksi tiada Tuhan selain Allah dan Muhammad sebagai Rasul Nya”, yang berarti bahwa sebagai seorang muslim kita harus menaati perintah Allah dengan hanya Allah SWT semata yang diibadahi dan menaati perintah Rasulullah SAW, membenarkan berita wahyu yang dia sampaikan, menjauhi apa yang beliau larang, dan tidak beribadah kepada Allah kecuali dengan cara yang beliau syariatkan. 
Andi Safriani

\section{Hukum Islam di Indonesia}

Eksistensi hukum Islam di Indonesia menarik untuk disimak selain karena negara ini memiliki penduduk yang mmayoritas muslim terbesar di dunia juga memiliki karakteristik keislaman yang berbeda dengan komunitas muslim lainnya. ${ }^{2}$

Di Indonesia dalam perjalanan sejarahnya yang relative panjang, pada akhirnya disepakati untuk membangun hukum yang berlaku untuk semua anak bangsa tanpa memperhatikan asal-usul bahasa, suku, ras, etnis, agama dan lainnya. Hukum dimaksud kemudian dikenal dengan hukum nasional. Hukum nasional dibangun berdasarkan 3 sumber hukum yaitu hukum adat, hukum barat dan hukum Islam.

Hukum Islam menempati posisi sentral dan menjadi inti serta jantung dari ajaran Islam itu sendiri. Robert Van Niel mengatakan bahwa di Indonesia, agama tidak dapat dipisahkan dari seluruh aspek kehidupan dan sejalan dengan itu kebijakan dalam hal agama tidak bisa dipisahkan dari kebijakan-kebijakan lain yang diterapkan terhadap masyarakat setempat, karena itu disadari bahwa Islam menjadi elemen penting dalam kultur kehidupan masyarakat Indonesia.

Makna hukum dalam pengertian sehari-hari di Indonesia, terutama dikalangan umat Islam sampai hari ini masih dihubungkan dengan ketetapn hukum Islam. Dengan tersebarnya Islam keberbagai persada nusantara terjadi proses islamisasi secara damai, sehingga kerajaan-kerajaan Islam mulai menggantikan tempat kerajaan sebelumnya.

Hukum dalam Islam merupakan sesuatu yang esensial yang mengendalikan sikap hidup penganutnya. Bila seseorang memeluk agama Islam maka secara otomatis ia mengakui hukum Islam dan ia wajib melaksanakannya dalam kehidupan pribadi maupun masyarakat.

Dalam bidang sosial kemasyarakatan, Islam memperkenalkan tradisi hukum baru di Indonesia. Ia menawarkan dasar-dasar tingkah laku sosial yang kurang lebih sama dibandingkan dengan yang berlaku sebelumnya. Di samping itu, Islam juga menyumbangkan konsepsi baru hukum untuk Indonesia.

\footnotetext{
${ }^{2}$ Arfin Hamid, Hukum Islam Perspektif ke Indonesiaan (Sebuah Pengantar dalam Memahami Realitasnya), h. 16
} 
Hubungan antara hukum Negara dan hukum Islam dapat dilihat baik secara normatif atau positif, hukum Islam yang telah diformulasi menjadi hukum nasional sudah cukup banyak diantaranya Undang-undang Perkawinan Nasional, Undangundang Pengadilan Agama, Undang-undang Pelaksanaan Haji, Undang-undang Pengelolaan Zakat, Undang-undang Perwakafan, Undang-undang Otonomi Khusus Aceh, Undang-undang Perbankan Syariah dan lainnya.

Memperhatikan Pancasila sebagai grundnorm dalam system hukum Indonesia dengan Ketuhanan Yang Maha Esa sebagai sila pertama yang dijelaskan oleh pasal 29 ayat 1 dan 2 UUD 1945, maka hukum Islam mempunyai peluang yang besar untuk menjadi bagian hukum nasional Indonesia. Perkembangan terakhir ini juga berlaku di Indonesia, baik dalam bentuk produk Undang-undang maupun pemikiran hukum yang dikembangkan oleh b erbagai lembaga dan individu.

\section{Tantangan Penerapan Syariat Islam di Indonesia}

Penerapan syariat Islam di Indonesia menghadapi tantangan atau challenge yang cukup serius. Masalahnya Indonesia ditakdirkan lahir sebagai bangsa yang heterogen (beragam) atau berwarna warni, bukan homogen (satu warna), dan hal tersebut direpresentasi oleh Pancasila dan Undang-Undang Dasar Tahun 1945 sebagai basic negara dan konstitusi, akibatnya seluruh rakyat Indonesia dalam hal ini warga negara Indonesia berkedudukan dan berhak mendapatkan perlindungan dan perlakuan yang sama dari negara tanpa memandang latar belakang agama yang dianutnya.

Persoalan yang cukup serius disini adalah masih banyaknya masyarakat, tokoh bangsa dan kaum intelektual yang memiliki kekhawatiran yang amat tinggi atas penerapan syariat Islam. Mereka khawatir penerapan syariat Islam ini akan melibas atau menafikkan keragaman atau kebhinnekaan yang ada dinegeri ini.

Kondisi tersebut diatas yang menjelaskan mengapa pendekatan political-legal penerapan syariat Islam di Indonesia selalu mendapatkan tantangan bukan hanya dari kalangan non muslim bahkan dari kalangan tokoh-tokoh Islam sendiri, taruhannya sangat serius yaitu eksisnya Indonesia sebagai bangsa kokoh bersatu, maka banyak tokoh-tokoh Islam atau organisasi Islam yang mengambil jalan panjang melalui cara 


\section{Andi Safriani}

transformasi sosial. Artinya masyarakat melalui lembaga-lembaga dan nilai-nilai sosial terus dikondisikan untuk semakin islami, kelompok-kelompok inilah yang akan mencegah pendekatan politik kenegaraan dalam penerapan syariat Islam, karena menurut mereka rakyat Indonesia akan menjalankan syariat Islam dengan sendirinya.

Lahirnya beberapa undang-undang yang Islami atau mengakomodasi kepentingan umat Islam di Indonesia, diantaranya seperti undang-undang zakat, Haji, perbankan syariah, anti pornografi dan lain lain, juga lahirnya peraturan peraturan daerah diberbagai daerah yang bernuansa Islami telah menjadi angin segar bagi kaum muslimin di Indonesia setidaknya dalam menghadapi tantangan penerapan syariat Islam yang diperjuangkan oleh umat Islam di Indonesia saat ini.

Upaya Positivisasi syariat Islam khususnya yang berhubungan dengan pidana Islam (Jinayah/Uqubat) sampai saat ini masih dalam bentuk wacana atau masih menjadi hukum yang dicita-citakan.

Pemikiran kearah tersebut banyak disampaikan oleh berbagai kalangan seperti para ulama, praktis, ahli hukum, cendekiawan muslim dan masyarakat yang concern terhadap hal tersebut, meskiopun hal ini menuai perdebatan namun hal ini dapat menjadi peluang besar bagi umat Islam untuk terus mewacanakan dan meneruskan kajian kearah kodifikasi hukum pidana Islam. Tentunya upaya ini dilakukan dalam rangka mencairkan pandangan umat yang selama ini masih beranggapan bahwa hukum Islam itu adalah suatu yang normative saja. 


\section{PENUTUP}

\section{Kesimpulan}

Perjuangan penerapan syariat Islam di Indonesia merupakan rangkaian sebuah proses atau jalan yang cukup panjang yang harus dilakukan oleh semua elemen atau komponen umat. Tantangan yang dihadapi dalam penerapan syariat Islam di Indonesia berupa tekanan politik dan lain-lain harus dihadapi baik melalui edukasi dan dakwah, penyebarluasan wacana dan juga perumusan lebih jauh hukum Islam dalam bentuk hukum positif haruslah terus dilaksanakan. Untuk menghadapi tantangan dalam penerapan syariat Islam di Indonesia kiranya semua komponen umat harus bersinergi, baik pemerintah maupun masyarakat atau umat Islam sendiri. Pemerintah sebagai penentu kebijakan dengan power yang dimilikinya hendaknya bekerja lebih agresif untuk menghasilkan produk-produk hukum yang bersumber dari ajaran Islam, umat Islam pun hendaknya mendukung setiap upaya pemerintah akan hal tersebut. 


\section{DAFTAR PUSTAKA}

Abd Somad. Penormaan Prinsip Syariah dalam Hukum Nasional, Kencana, Jakarta. 2010

Arfin Hamid, Hukum Islam Perspektif Keindonesiaan (Sebuah Pengantar dalam Memahami Realitasnya), Umitoha Ukhuwah Grafika, Makassar. 2011

Ichtianto. Hukum Islam dan Pembangunan Nasional. Radar Jaya, Jakarta. 1990.

Ali, M. Daud. Hukum Islam Pengantar Ilmu Hukum dan Tata Hukum Islam Indonesia, Rajawali Press, Jakarta. ,2001.

Usman, Suparman., Hukum Islam: Asas-asas dan Pengantar Studi Hukum Islam dalam Tata Hukum Indonesia. 2002.

Jamaluddin, Nur. Penerapan Syariat Islam di Indonesia. Isfimalaysia.wordpress.com www.google.com “Hukum Islam di Indonesia”. Diakses 3 Mei 2013.

www.rumahfiqih.com “Menegakkan Syariah Islam di Indonesia”. Di akses 5 Juni 2013. 